\title{
O museu como um prazer de vida: entrevista com Otávio Balaguer
}

Entrevista por Beatriz Gasques Favilla e Gabriel Yukio Shinoda Oliveira

Transcrição por Beatriz Gasques Favilla, Gabriel Yukio Shinoda Oliveira e Pedro José de Carvalho Neto

Revisão por Gabriel Yukio Shinoda Oliveira, Guilherme Oliveira Souza, Marina de Almeida Spinola, Matheus de Paula Silva e Pedro José de Carvalho Neto

DOI: 10.11606/issn.2318-8855.v9i2p237-263 


\section{entrevista}

O museu como um prazer de vida

Logo cedo, Otávio Balaguer já percebia em si um gosto de ir aos museus, onde ele encontrava seu lugar de lazer. Hoje mestre em Museologia pela USP, ele trabalha com a organização desses espaços, já tendo passado por vários museus importantes de São Paulo, como o Museu de Arte Sacra, o Museu de Arqueologia e Etnologia da USP e o Museu Paulista. Desde jovem também percebia sua vontade de ingressar no curso de História e assim foi em 2012! Encontrou nele um espaço marcante de sua vida.

Na entrevista, Otávio falou não só sobre sua vida, mas também sobre o cotidiano interdisciplinar dos museólogos, que agrega uma multiplicidade de áreas e profissões. Otávio ainda faz um apelo nesse momento de pandemia: ele não nega a importância das medidas de isolamento social, mas, no momento em que vê estabelecimentos públicos sendo novamente abertos, entende que os museus, com todas as condições sanitárias de segurança possíveis, deveriam ser novamente reabertos para seu espaço social não ser apagado durante esse processo.

Boa leitura a todas e todos!

Revista Epígrafe: Bom, Otávio, já indo direto para as questões aqui... Nós queríamos saber como é que foi a sua aproximação com a área de História. O que te levou a fazer esse curso?

Otávio Balaguer: Bom, eu sempre gostei de História, desde que eu era bem jovem. Então tenho memória de ler textos, livros de História desde mais ou menos os meus doze anos. Enfim, eu sempre gostei bastante da disciplina, apesar de nem sempre gostar da maneira como ela era oferecida no colégio; eu nem sempre estava feliz com como a gente tinha que fazer as coisas, com como a didática funcionava, mas muito interessado pelo conteúdo. E aí tive essa certeza de que gostaria de estudar História, 


\section{entrevista|}

Otávio Balaguer

acho que ainda cursando o Ensino Fundamental, durante o Ensino Médio isso foi ficando mais claro... Titubeei, porque a gente sempre pensa “o que será que eu vou fazer da minha vida?", "será que isso é determinante?"... Pelo menos para mim, o ensino superior se colocava dessa maneira. Mas no final das contas, fui para a História, sem dúvida. Bom, isso quanto à História. E sempre gostei dos museus. Sempre, sempre gostei de museus também; desde muito pequeno, acompanhado da História estavam os museus. Então sempre foram muito interessantes para mim.

Revista Epígrafe: E a experiência da graduação para você, como é que foi? Teve algum professor, alguma coisa que te marcou?

Otávio Balaguer: Ah, a graduação em História, não sei se só porque ela é em História ou se é porque foi a graduação em si, mas foi muito marcante para mim como um todo. Então estar na universidade, ver a USP, ver a Faculdade de Filosofia, abriu demais as minhas expectativas de vida. Eu não tinha consciência de tudo o que eu poderia acessar até o momento em que estive lá. Então fui muito a fundo na História e na vivência universitária também. Participei de diversas ações; logo no primeiro ano já ingressei no Programa de Educação Tutorial [PET] e aí fiquei durante dois anos atuando com as frentes de ação que o programa mantinha na época, então fui recebido por um pessoal que já estava há um tempo.

A tutora na época era a professora Megiani, Ana Paula Torres Megiani, foi uma das pessoas marcantes na minha graduação também, desde o início caí na turma dela de Ibérica; adoro História Ibérica, contra todas as expectativas de muitos dos graduandos em História... E o PET também abriu demais as minhas perspectivas de atuação. Logo lá, já fui me inserir em projetos de extensão universitária, então trabalhamos com a discussão do processo de tombamento em uma região da cidade 


\section{entrevista}

O museu como um prazer de vida

de São Paulo e foi ali que eu aprendi também mais sobre pesquisa, que a gente desenvolvia os seminários, que eram um processo de pesquisa que amadureciam durante um tempo, na minha época era um ano, e depois elas eram apresentadas em forma de seminário. Então foi lá que eu estudei micro-história, com a Marina, uma colega da minha época, a gente trabalhou com Carlo Ginzburg, O Queijo e os Vermes era uma sensação, pelo menos no meu ano de entrada; era um texto muito interessante, e a gente falou: "vamos estudar isso". E outros projetos paralelos, né, a gente discutiu muita coisa na minha época. Enfim, é porque o PET é bem orgânico, então já não sei hoje quais caminhos que o PET está traçando, mas eu sei que só

melhora. É um programa, assim... É uma pedra preciosa da História. E a gente leu Benjamin, isso foi muito marcante para mim também, porque depois eu fui retornar nessas reflexões do Benjamin; a gente leu o Volume I do Obras Escolhidas, foi super importante; a gente leu História da Loucura do Michel Foucault também, outro texto que pfff... Estoura a cabeça.

E aí eu entrei muito na linha de frente com o pessoal da Fábrica de Cimento Portland Perus, que é o patrimônio que estava em processo de luta pelo tombamento. Até hoje existe muita coisa lá... Na minha época, ainda, o PET acabou se afastando desse processo, dessa discussão. Mas também tinha uma outra frente que era a frente do ensino, que era muito ansiada pelo PET e eu sei que, posteriormente, ele conseguiu se inserir mais fortemente nessa área; na nossa época, a gente ainda não trabalhava diretamente com Ensino de História. E foi aí que começaram a se abrir as coisas para mim. Então eu vivi muito a universidade, também sempre trabalhei, desde o começo eu me inseri em bolsas, como o próprio PET ou outros tipos de bolsas e outras atuações. E isso sempre muito ligado à graduação, então eu também nunca... Eu sempre me mantive dessa forma, trabalhando na universidade, mas nunca fora dela. Então não sei como é você trabalhar fora da universidade para se 


\section{entrevista|}

Otávio Balaguer

manter lá, mas consegui associar todo o meu processo formativo a uma maneira de remuneração também e de estabilização. Bom, de modo geral, a graduação em História foi excepcional para mim; eu me entendi no mundo e me entendi pessoalmente, me entendi na minha família, na minha sociedade e foram várias reflexões, assim, ao longo dos anos.

Revista Epígrafe: Como que era a relação, para você, com os museus antes da graduação? Você já visitava bastante? Você gostava ou você não curtia tanto e passou a gostar a partir da graduação?

Otávio Balaguer: Eu já visitava bastante museus antes da graduação. Eles eram, para mim, um lugar de lazer; lazer para mim era museu. Enfim, assim, isso era muito claro. Eu ia passear em museu; e aprender também, porque você sempre recolhe alguma coisa do lugar deles. Então eu não ia com objetivos muito claros. Claro que você ia ver uma exposição, alguma coisa assim, mas não ia lá para fazer um trabalho de colégio, entende? Eu não ia nos museus para... Eu ia realmente para lazer. E eu também tive a facilidade de os meus pais me ajudarem nisso, porque eles me levavam a alguns lugares.

Quando eu entrei na graduação, eu fui ganhando autonomia, então fui podendo me deslocar, porque eu me tornei adulto; entrei com dezoito anos na graduação, então antes também eu não me deslocava com tanta facilidade. E os museus continuaram sendo minha distração. Então não só na cidade de São Paulo, mas em qualquer lugar que eu esteja, são os primeiros lugares que eu vou, porque eu acho que, pelo museu, dá para você entender um pouco do que está acontecendo ali.

Revista Epígrafe: Você chegou a ser monitor de uma disciplina de graduação, não? E 


\section{entrevista}

O museu como um prazer de vida

como é que foi a experiência da monitoria?

Otávio Balaguer: Ah, foi incrível. Foi, também... Nossa, está tudo muito incrível, né, mas enfim [risos]... É porque foi muito bom, mesmo. É, durante... Como eu disse, eu entrei na graduação, já iniciei no PET e eu tinha interesses muito difusos. E isso, de modo geral, é um problema para a pesquisa acadêmica, porque a pessoa curte a academia, ela é incentivada a fazer seus recortes e ir por um caminho. Então, quando você chega na Faculdade de Filosofia, já está tudo muito claro, porque tem um sistema que está funcionando há muito tempo, enfim... E é um curso de graduação, pelo menos na época em que eu entrei, bastante focado em pesquisa e na produção acadêmica, na produção científica. E quando você chega lá, se coloca tudo isso: “o que você quer estudar? O que você quer fazer?"; eu falei: "ué, eu gosto de um monte de coisa.". Eu adorava, também, quando eu entrei na graduação, Idade Média; nossa, eu viajava na Idade Média. Fiz curso de Latim, estudava um monte de coisas, para mim era fascinante aquele período bagunçado. E aí eu me aproximei, eu fiz História Medieval I com a professora Maria Cristina Correia Leandro Pereira, que também achei, assim, uma pessoa incrível; e aí adorei a perspectiva da professora Maria Cristina, fui participar do laboratório dela, fiquei durante um tempo participando das discussões e aí acabei sendo monitor da disciplina dela, que foi uma experiência ótima; ela é uma ótima orientadora nesse sentido profissional, de você aprender ali como é que é o funcionamento de uma disciplina. E poder fazer isso na graduação é incrível, porque depois eu fiz na pós também, aí com outra perspectiva ainda. E foi muito legal. Para quem gosta de ensino, é muito interessante. Ensino de adultos, né, também, porque a graduação é focada no ensino para pessoas adultas, né? Não é como no Ensino Básico. Então eu acho que é muito interessante, eu gostei muito dessa perspectiva, me abriu mais um pouquinho essa portinha de pesquisa, sabe? 0 


\section{entrevista|}

Otávio Balaguer

PET abriu um pouquinho, aí o PEEG [Programa de Estímulo ao Ensino de Graduação] abre mais um pouquinho. E aí eu acho que fui abrindo aos poucos as portinhas, sabe?

Ah, só para concluir, agora. Eu comecei dizendo que meus interesses eram difusos, né? Então, é justamente isso. Essas portinhas que eu fui abrindo, elas foram me sinalizando coisas, e às vezes eu fechava uma portinha e depois abria outra portinha. Eu fui experimentando algumas coisas, até chegar no ponto em que eu cheguei, que, aí sim, eu me aquietei. Mas eu tive essa possibilidade de percorrer vários caminhos.

Revista Epígrafe: E pegando esses seus pontos difusos dentro da graduação, você chegou a fazer pesquisa ou estágio? Como foram essas experiências?

Otávio Balaguer: Então, a pesquisa, formalmente, como uma iniciação científica, durante a graduação, eu não desenvolvi, porque eu estava nesses interesses difusos. Então, a gente teve uma experiência de pesquisa no PET, lá eu desenvolvi uma pesquisa, de certo modo, que foi orientada, na época, pelo Miguel Palmeira, que veio depois da Megiani; enfim, foi uma espécie de investigação, mas não de uma maneira formal.

O que eu usei como iniciação científica, de algum modo, na graduação, foram os trabalhos dos cursos que eu fazia, porque uma coisa que eu encarava de uma maneira muito séria eram esses trabalhos. Então eu aprendi a escrever na graduação, resumindo. Assim, a gente não chega sabendo, mas eu sinto pela minha experiência que se eu não tivesse me colocado nesse exercício de produzir os trabalhos, eu não teria aprendido a escrever também. E eu não sei se eu escrevo hoje, mas enfim, eu tenho alguma coisa já que eu aprendi nesse processo. E aí fui fazer estágio. Como eu estava no PET já havia dois anos, falei: "veja só que bom, acho que este ciclo está se 


\section{entrevista}

O museu como um prazer de vida

fechando para mim, estou interessado em ir para os museus.". Foi no mesmo momento em que eu fui me desligando lá do Laboratório de História Medieval, o LATHIMM.

E aí eu comecei a me aproximar dos museus, que nunca tinham estado longe de mim. Mas confesso que as disciplinas que eu via na grade da História nem sempre me interessavam. Tem Arqueologia, que depois eu me aproximei muito, acho super interessante, mas ela não está de fato nos museus, né? Tinham as disciplinas de Museologia que eu só fui fazer bem no finalzinho da graduação. Porque nos dois anos seguintes ao PET, que foi de 2014 a 15 e de 15 a 16, eu fui estagiário do Museu Paulista, do Museu do Ipiranga; estagiário de um projeto de pesquisa da professora Vânia Carneiro de Carvalho, que trabalha com ambiente doméstico e questão de gênero, essa é a investigação dela. E eu fui trabalhar no projeto de exposição O Morar Paulistano. O que é que é O Morar Paulistano? Ele é um produto dessa pesquisa que vem sendo desenvolvida no Museu Paulista, encabeçada por ela e um grupo de outras pessoas, que pretende problematizar o ambiente doméstico da cidade de São Paulo, ele tem um recorte para isso. E aí eu entrei para trabalhar nos processos museológicos dessa coleção; eu fiz inventário, tombamento, fiz tudo o que você pode imaginar... Todos os processos que se dão diretamente com os objetos. E aí foi incrível, porque trabalhar dentro do Museu Paulista fechado, porque estava em obras, sozinho no corredor lá em cima, eu e minhas fichas e os objetos, foi uma experiência muito interessante. Então acho que sacramentou... esses dois anos de trabalho com a professora Vânia foram sacramentando esse meu interesse por museus que já vinha desde a infância e que ganhava forma durante a graduação.

Quando eu terminei esse processo, eu falei: “eu vou prestar o mestrado em Museologia". Por quê? Eu já estava pensando outros problemas, paralelamente a isso, coisas que me inquietava, questões que eu tinha envolvendo os museus, e outro 


\section{entrevista|}

Otávio Balaguer

tema de pesquisa que estava me aproximando por meio do Departamento de Letras Orientais da Faculdade de Filosofia, que são os estudos judaicos. Eu fui me aproximando dos Estudos Judaicos no finalzinho da graduação, também por interesses muito difusos; sempre gostei um pouco de história judaica, na Idade Média e na História Ibérica, e aí eu fui lá fazer umas disciplinas. Aí fiz disciplinas com o professor [Alexandre] Leone, com a professora Marta Topel, antropóloga incrível, nem sempre muito bem entendida também [risos]. Mas enfim... E aí o que é que aconteceu nesse meio-tempo? Aqui na cidade de São Paulo, foi inaugurado um museu judaico, e que eu estava lá visitando e acompanhando desde a inauguração, e fui pirando naquele museu. E aí eu falei: "gente, mas é isso! Eu preciso entender o que está acontecendo aqui.". Fui formulando questões. Ao mesmo tempo, eu estava fazendo mais uma disciplina de Museologia, no Museu de Arqueologia e Etnologia, que é a disciplina Educação Patrimonial, com o professor Camilo de Mello Vasconcellos, que veio a ser meu orientador posteriormente. Então os interesses foram afunilando. E foi assim, na beira do final da graduação, aos 45 do segundo tempo, eu entendi o que eu queria fazer. E aí eu queria pesquisar, obviamente. E aí prestei o mestrado e engatei a graduação no mestrado.

Revista Epígrafe: Como é que foi essa sua experiência no mestrado em Museologia?

Otávio Balaguer: Então, na USP existe uma área de Museologia que fica no Museu de Arqueologia e Etnologia, o MAE, com docentes, pesquisa de pós-graduação e etc. $E$, enfim, como eu disse, eu já estava convergindo para a Museologia, e aí vi minha graduação terminando; vi meu estágio terminando; vi meu interesse na pesquisa e as perguntas que surgiram quando eu visitava aquele espaço e quando eu lia os textos, e aí eu falei: "vou tentar desenhar o projeto de pesquisa". Isso foi tudo muito 


\section{entrevista}

O museu como um prazer de vida

autônomo, eu não contava com um orientador de iniciação científica, como eu disse para vocês, e eu não contava com um "contatinho" também, em termos informais, da parte dos professores. Porque, assim, a pesquisa acadêmica é um pouco esse processo: você bate cabeça, tem que encontrar alguém, isso tem que dar certo... E aí eu fiz essa disciplina com o professor Camilo; no final da disciplina discuti várias coisas com ele, apresentei a minha ideia e falei: "Ah, olha, tem isso, isso e isso que eu estou pensando e etc., estou querendo prestar o mestrado em Museologia. Eu posso pedir para você me ajudar na redação desse projeto? Porque eu preciso de alguém que me apoie nessa revisão e etc.". Ai ele falou para mim: "Nossa, mas você já vai prestar o mestrado? Poxa, você está terminando a graduação, você tem certeza disso?". Aí eu falei para ele: "Ah, eu tenho. Preciso continuar, senão vou perder o meu timing". Eu escrevi sozinho esse projeto, gente, sozinho; dando nó aqui, pesquisando isso, associando Estudos Judaicos com bibliografia de Museologia... E nesse momento, eu ainda não estava teórica e metodologicamente inserido na Museologia, isso eu fui construindo. Então eu sabia, mais ou menos, o que era museu, óbvio, trabalhava com os museus, entendia os museus, mas eu não tinha, assim, a teoria dos museus. Então fui estudando, ao longo de um semestre, para me formar, literalmente, para construir esse projeto, e também para depois me preparar para a prova, passar no programa de Museologia. E aí o projeto aconteceu, mandei para o Camilo, ele fez comentários super legais, apoiou muito, muito profissional a postura dele, nossa aproximação foi totalmente transparente nesse sentido. E aí ele me apoiou muito nesse processo, porque foi o que ele pesquisou no trabalho dele, sabe? Então, enfim, ele orienta pessoas assim. E aí fui me preparando, fiz o projeto, conversamos algumas vezes, aí ele falou: “Olha, veja bem, agora que a gente já conversou, a gente não pode mais conversar, você vai participar do processo seletivo, então a gente vai se ver aí no dia na banca de seleção; boa sorte". E aí fui estudar para Museologia. 


\section{entrevista|}

Otávio Balaguer

A partir da bibliografia do processo seletivo do programa fui entender os processos museológicos mais profundamente, fui entender as metodologias que você pode usar, as abordagens para os estudos dos museus, e outras tantas coisas que são importantes. E aí, para a minha surpresa, eu tirei nota dez na prova teóricometodológica de Museologia e eu fiquei chocadíssimo [risos], porque eu estava estudando durante seis meses o tema; foi muito interessante esse processo todo. Ele é desgastante, você fica nervoso, porque tem muita coisa em jogo, né?

E eu percebi que eu precisava ter uma bolsa, também, para desenvolver essa pesquisa; isso era muito caro para mim naquele momento, eu precisava ter uma bolsa. E para ter uma bolsa naquele programa, eu precisava passar em uma posição boa, porque todo mundo é ranqueado. E aí ranqueei, passei e ganhei a bolsa e desenvolvi a pesquisa, que foi uma pesquisa voltada a entender a identidade judaica no Brasil construída dentro daquele lugar que é o museu. O museu se chamava, na época, Memorial da Imigração Judaica no Brasil, hoje ele acabou ampliando seu escopo de trabalho, teve uma nova área expositiva, acervos novos, e se chama Memorial da Imigração Judaica e do Holocausto; fica no Bom Retiro, que é um bairro tradicionalmente de imigrantes e, entre eles, muitos judeus. Eu cheguei lá e falei: "Quero entender o que é que é 'judeu' nesse lugar.", e aí fui problematizar um pouco a História da imigração judaica no Brasil, o conceito de memória e o conceito de memória judaica e identidade judaica, para tentar ver qual era a mensagem que queria se passar naquele espaço, naquele museu. E o professor Camilo me ajudou. No começo, meu projeto de pesquisa se chamava História, Memória e Identidade no Memorial da Imigração Judaica no Brasil, e aí durante o processo, foi amadurecendo, e hoje a minha dissertação, que foi defendida já, se chama Kehilat Israel: um estudo de narrativas expositivas sobre a imigração judaica. E aí eu me tornei Mestre em Museologia pelo programa. Foi um processo muito legal, o da pesquisa. 


\section{entrevista}

O museu como um prazer de vida

Durante a minha pesquisa, eu concorri a uma bolsa do Santander Universidades, em parceria com a Aucani da USP, e fiz um curso de formação na Universidade Complutense de Madrid, que era dedicado à reflexão sobre o museu contemporâneo, então o curso se chamava Repensar el museo, que foi conferido por profissionais, professores e pesquisadores da USP, da Universidade Nacional Autônoma do México, da Universidade de Buenos Aires, da Universidade de Barcelona e da Universidade Complutense de Madrid; foi também uma experiência incrível, porque era um curso voltado para o mundo ibero-americano, que é outra coisa que existe muito na cultura do campo dos museus, que é a discussão das relações não só entre a América Latina, mas com a Europa Ibérica, que tem essa origem colonial; às vezes, os canadenses gostam de se enfiar também nesses debates, porque eles se sentem meio latinos, o pessoal do Quebec, apesar de estar numa coisa bem diferente, né? É muito interessante, na verdade, esse curso.

E aí me tornei mestre em Museologia. Só que isso não me torna museólogo. Por que? A Museologia é uma profissão regulamentada no Brasil, assim como a Medicina, a Engenharia, e agora a História também foi regulamentada. Então, para eu me tornar um museólogo, eu tenho que me colocar lá diante do Conselho Regional de Museologia e passar pela validação para receber um registro que vai controlar o meu exercício profissional, então eu não posso trabalhar como museólogo se eu não tenho esse registro. Eu não posso me dizer museólogo, também, nem informalmente. Existe aí uma fiscalização nacional, que nem a os dentistas, ninguém pode dizer que é dentista se não está lá no CRO; ninguém pode dizer que é médico, engenheiro; agora os historiadores também vão entrar nesse processo. Quando tudo finalizar, só vai ser historiador quem é regulamentado. E também, prós e contras: só vai poder escrever História quem é historiador. Enfim, é outra discussão. Mas isso acontece na Museologia. É uma área que é grande e pequena, ao mesmo tempo, porque os 


\section{entrevista}

Otávio Balaguer

profissionais de museus são inúmeros, imensos, muitos, só que os museólogos são menos, são poucos que têm essa habilitação, porque quando você estuda Museologia, você se habilita para certas coisas específicas da profissão do museólogo, que é responsável pela gestão e articulação de todos os processos museológicos do museu. Então, por exemplo, um museólogo, ele é responsável por elaborar, assinar, implementar e acompanhar o exercício de um documento chamado Plano Museológico, que é uma espécie de plano diretor, que nem as cidades têm os planos diretores, os cursos têm os seus planos... O museólogo é responsável por esse processo; e também por atuar em várias linhas de trabalho lá. E aí, tudo isso para dizer que é uma área que é grande, mas ao mesmo tempo, é pequena. Então eu obtive meu diploma e, depois de um processo um pouco longo, por $N$ questões, eu me tornei museólogo. Hoje eu sou museólogo registrado. Sou registrado sob o número 359, categoria II, no Conselho Regional de Museologia da $4^{a}$ região. E posso exercer esse cargo, mas não atuo como museólogo; eu atuo como técnico em Museologia, numa associação cultural, que é uma organização social de cultura responsável pela gestão de alguns museus do Estado de São Paulo, em parceria com a Secretaria de Cultura e Economia Criativa, e da articulação e do trabalho do Sistema Estadual de Museus de São Paulo, que é uma instância da Secretaria responsável pela articulação e qualificação dos equipamentos museológicos do Estado. E aí trabalho na Associação Cultural de Apoio ao Museu Casa de Portinari, mais conhecida como ACAM Portinari, que é uma organização social de cultura do Estado de São Paulo.

Revista Epígrafe: Como é que você enxerga a relação entre suas experiências na graduação e também no mestrado com seu trabalho cotidiano nos museus?

Otávio Balaguer: A graduação em História oferece muitas habilidades e competências 


\section{entrevista}

O museu como um prazer de vida

que você usa na sua vida de modo geral; enfim, toda formação te proporciona isso. Mas quando o historiador chega no museu... Primeiro, como o historiador pode se inserir no museu, na vida museológica? Dentro desse fluxo de trabalho, dessa cadeia operatória que o museu tem, o historiador pode se inserir em vários lugares. Ele pode acabar se qualificando e se inserindo como museólogo, porque os museus exigem qualificação de todas as formações; você nem sempre consegue chegar lá, historiador, e dar conta de tudo o que está acontecendo, pois o museu exige muita qualificação, até de quem é da área museológica; e aí, dentro do museu, o historiador pode se inserir, a partir da sua própria formação em História, numa área de pesquisa, por exemplo; os museus têm setores próprios de pesquisa... pesquisa de acervo. Na área de curadoria de acervos e exposições, que ele vai trazer todo esse know-how da História para qualificar o seu acervo, porque a função de um museu é preservar e comunicar um patrimônio; então, um museu tem objetivos a serem atingidos, ele tem missões, valores, visões.

Se você é um museu público, você tem expectativas da sociedade em relação a você; por exemplo: você tá em debate com a gestão pública, e a gestão pública te coloca metas, te coloca produtos a serem executados pela equipe de um museu para atingir as expectativas de uma sociedade, que é representada como? Os museus possuem conselhos. Então pessoas da sociedade discutem a função daquele equipamento museológico, então você como um cidadão vai falar assim, “olha, eu não vejo que o museu da Carochinha tá discutindo a História da vila da Carochinha, que eu acho que é a importância dele, então eu acho que tem que repensar esse processo, porque é o museu da Vila da Carochinha, mas ele não tá falando da Vila da Carochinha", por exemplo. Enfim, foi um exemplo bem assim... Mas a sociedade tem expectativas em relação ao museu e o museu tem que atender essas expectativas, então nesse processo precisa de muita gente, de muita habilidade. E aí entra o 


\section{entrevista|}

Otávio Balaguer

historiador na pesquisa...

O historiador pode entrar na educação se ele tiver se qualificado para ser um bom educador, se ele tiver pensado a Educação Museal. Na educação não formal, se ele tiver sua licenciatura, eu acho que é um espaço que tem muitos historiadores que nós conhecemos que trabalham e que se realizam demais na Educação Museal. Nós temos metas para educação museal também no Brasil e em outros setores. 0 historiador entra em vários campos, mas eu faço essa ressalva: eu não acredito que ele não precise se qualificar para isso, entende? Eu acho que tem um processo constante de qualificação que o historiador também tem que estar disposto a fazer no museu.

Eu mesmo nunca me aproximei muito do setor educativo; eu já fiz muitas ações, participei de ações educativas; durante a graduação eu tive experiências educacionais, trabalhei com educação não formal também, fui dar aula em cursinho, pensar a educação, fiz minha licenciatura com muita dedicação. Mas eu sabia que não era na área da educação no museu que eu queria trabalhar, então não fui. E aí o historiador se insere nesse fluxo de trabalho. E se ele quiser se qualificar, se tornar um museólogo, ele pode se tornar um museólogo. Ou ele não precisa ser um museólogo, ele pode ser só mestre em museologia também, se ele quiser.

E aí, enfim, as pessoas acusam muito o Estado de São Paulo principalmente, porque na história da museologia do Estado de São Paulo, a pós-graduação, ela é muito forte. Então, aqui existe uma tradição que consolida a museologia como pós stictu sensu... Aqui o profissional de museu é interdisciplinar. Então, consequentemente, o museólogo tem várias vocações, anda por várias disciplinas. Então, o que é ser museólogo para eu, Otávio, e o que é ser museólogo para outra pessoa são coisas diferentes. Se uma pessoa está inserida na área de conservação e restauração, a perspectiva dela é conservação; eu não, eu sou da comunicação 


\section{entrevista}

O museu como um prazer de vida

museológica, é outro campo. Enfim, todos nós somos museólogos, porque um só não vai dar conta de tudo, em nenhuma formação, né?

Eu queria dizer tudo isso para falar que os historiadores são inúmeros na área dos museus no Estado de São Paulo. São assim... Acho que junta aí com os arquitetos também que participam muito nos museus, são um grupo que, entre parênteses, na brincadeira, dominou. Então, grandes referências da museologia do Estado são historiadores. E aí os historiadores que se interessam por museus e gostam de museus eu digo: qualificai-vos e vamos somar!

Revista Epígrafe: E aproveitando que você tocou rapidamente no assunto, a gente queria saber sobre essa relação entre o museu e a questão educacional...

Otávio Balaguer: Eu acho que o museu é um lugar incrível de aprendizado para todas as faixas etárias. Quando a gente fala de educação, acho que as pessoas pensam mais em educação básica, pensam em crianças nos museus e, de fato, o grande público nos museus brasileiros é o público escolar, ainda; isso é um debate: o público escolar no museu é importante, mas é importante também que outros públicos possam acessar os museus; existem muitas reflexões acadêmicas sobre isso, sobre educação museal, acho que é um debate super importante.

Nesse momento de pandemia, houve vários problemas nos equipamentos museais que tiveram que fechar no mundo inteiro; existem pesquisas do Conselho Internacional de Museus que falam que muitos museus não vão reabrir, que não vão ter condições técnicas, operacionais e financeiras de reabrir. E nesse embate todo, o que que acontece? Nós vimos que muitos educativos foram dispensados; isso é um problema na perspectiva da gestão museal, porque não é assim que funciona. Como que um museu funciona? Como eu disse, é uma cadeia, uma série de ações 


\section{entrevista|}

Otávio Balaguer

interligadas dentro do museu e o eixo central é a curadoria. Normalmente, quando a gente ouve curadoria, a gente ouve numa perspectiva da organização de exposições, dos artistas... E, nesse processo, o setor educativo é central, ele tá totalmente integrado; se você não consegue comunicar aquilo que você produz, tem um problema no seu processo. Os educadores são a linha de frente dos museus... Os educadores, os recepcionistas, os bilheteiros, segurança, esse pessoal todo é museu; a gente tem dificuldade de olhar dessa maneira. Você olha para o educador e chama ele de monitor, por exemplo, não entende que o processo dele lá é educativo. Mas toda essa cadeia está organizada para fazer a comunicação das exposições; para comunicar conteúdos; para trabalhar questões; então o setor educativo é central na existência de um museu. Ele tá na linha de frente da comunicação das pesquisas e ele tá realizando as pesquisas; e na linha de frente das exposições, ele tá organizando, produzindo as exposições.

E aí a gente tem aquele debate, educação formal ou educação não formal. Museu não é o lugar em que você vai ver conteúdos escolares; eles podem estar, sim, relacionados ao conteúdo da escola, mas ele não é complemento do que você vê lá. O museu tem um conhecimento para ser compartilhado que é construído por ele próprio. Então cada ação que um educador executa tem começo meio e fim, tem um objetivo a ser atingido. É que nem quando você faz um plano de aula: isso é uma ação educativa, ela tem todo um processo para ser executado. Então, quando você vai ao museu, você não vai aprender a cartilha, você não vai rezar a cartilha, o museu não serve para isso; a coisa mais interessante do mundo é você ir lá observar um artefato - não precisa ser uma coisa material, também, pode ser uma questão, o museu pode te apresentar uma pergunta, e ele pode utilizar um objeto para isso; você vai entender, descobrir outras relações possíveis observando um objeto para além daquilo que você entende como o uso dele, porque o museu tira o objeto de 


\section{entrevista}

O museu como um prazer de vida

circulação, o objeto se torna um semióforo, que é uma categoria criada por um pesquisador chamado Kristoff Pomian, que fala que o objeto, quando musealizado, ele fica descolado; ele perde o seu valor de circulação e ele tem outro significado embutido.

Revista Epígrafe: Nessa linha, você poderia relacionar as funções dentro do museu, como curadoria e educativo, com as funções do historiador?

Otávio Balaguer: Então, o historiador traz essa perspectiva única; eu acho que uma contribuição excepcional que os historiadores têm no campo dos museus é essa habilidade de conseguir localizar as coisas. Eu acho que ele coloca as coisas no seu lugar, assim, ele tem essa leitura, capacidade de tecer relações, muitas relações; e aí ele chega ao museu e ele localiza aquele museu, por meio da história, de consciência social, da historicização dos processos. Claro, cada museu tem as suas perspectivas, a sua função, né; existem várias dinâmicas, vários tamanhos, vários objetivos, vários propósitos. Mas quando você vê aquele museuzinho lá no interior do mundo, com acervos constituídos por memorialistas, doações de famílias, ele tá lá jogado, não tem muito um porquê de existir, porque ele perdeu a sua autoconsciência; o historiador chega lá e consegue proporcionar consciência àquele museu, eu sinto isso! E aí, no educativo, o museu é qualificado no processo de construção do conhecimento, de colaboração com esse outro que é o público que está lá e ele tem todos os mecanismos para propor as perguntas; porque eu acredito que o museu está disponível para nós para colocar perguntas. É claro, você consegue dados objetivos quando você vai ao museu, porque ele tem uma tabela informacional lá, mas não é necessariamente por isso que você vai lá.

Por exemplo, você vai num museu olha os artefatos indígenas e sai falando 


\section{entrevista|}

Otávio Balaguer

"olha só, têm indígenas no Brasil"; bom, se alguma pessoa não tinha consciência disso, talvez já foi um passo para ela, agora ela reconhece que existem indígenas no Brasil. A função daquele museu foi cumprida de algum modo. Mas é muito mais interessante para mim sair do museu entendendo que o povo Guarani tem uma temporalidade, um conceito de tempo muito diferente do meu; que por isso ele também tem um conceito de deslocamento, de vida, de relação com a terra que é muito diferente da minha. Você aprende isso, você consegue ter essa consciência no museu, observando uma exposição, conversando com o educador. Então essas reflexões, esses embates epistemológicos, eu acho que o museu joga isso na sua cara, porque o museu trata de cultura, sociedade, movimento. Então sempre tem debate epistemológico no museu.

Revista Epígrafe: E seguindo nessa linha, qual que é a diferença, por exemplo, entre um museu histórico e um museu de arte? Dá para o historiador exercer o mesmo papel, o mesmo tipo de função dentro dessas duas instituições?

Otávio Balaguer: Olha, as funções se tocam muito, mas existe uma diversidade de tipologias de museus e o que determina essas tipologias. O museu se dizer etnográfico, se dizer histórico ou se dizer de arte, é o olhar que ele vai dirigir ao objeto. Então, num museu histórico, podem ter telas, podem ter pinturas; um museu de arte pode ter objetos, que também podem ser entendidos como objetos históricos; mas o olhar e a pesquisa que vai ser desenvolvida nele está determinado por essa tipologia com a qual ele se identifica.

O historiador pode trabalhar num museu de arte ou num museu de História, e aí as pesquisas que ele vai realizar e o caminho que ele vai trilhar depende desse conjunto de procedimentos estabelecidos pelo museu. O museu de arte quer discutir, 


\section{entrevista}

O museu como um prazer de vida

talvez, muito mais profundamente uma composição, uma estética, ele quer fazer uma discussão metodológica, também do processo do pintor; talvez num museu de História você queira falar de uma representação que tem lá, então essa tela representa algo que tem outras tantas relações. Nós podemos ter, por exemplo, objetos arqueológicos num museu de História, mas um museu arqueológico, eu acredito, ele proporciona um olhar muito mais qualificado para arqueologia do que um museu de História. E, enfim, tem museus que conseguem dar conta de tudo isso, tem esses mega museus no mundo, aqui no Brasil nós temos alguns que tem essa diversidade de tipologias, mas a gente tem muitos na Europa, porque eles colonizaram o sistema solar inteiro, então eles têm museus que foram compostos por objetos que foram saqueados de diversas culturas, de diversas origens, de diversas materialidades. Aqui no Brasil quem dava conta disso era o Museu Nacional, que foi vítima de um incêndio terrível há dois anos atrás; no caso de São Paulo, os museus foram se especializando.

Revista Epígrafe: Queremos saber um pouco do seu cotidiano de trabalho na Associação Cultural de Apoio ao Museu Casa de Portinari... Pode ser também um pouco sobre seu trabalho no Museu Paulista. Antes da pandemia, é claro.

Otávio Balaguer: No Museu Paulista, que foi meu primeiro trabalho direto com museu, era super divertido; era interdisciplinar, porque como eu processei a coleção toda, eu passava por diversos departamentos: quando eu estava trabalhando com fotografias, eu tinha que ir setor de documentação histórica e iconografia para trabalhar com textos e fotografias; quando eu estava trabalhando com objetos, eu ia no setor de objetos. Em cada área dessas eu fui beliscando o conhecimento dos técnicos, aprendia como higienizar uma peça, como descrever objetos. 


\section{entrevista|}

Otávio Balaguer

Parte muito importante do trabalho de profissionais em museus é a qualificação da informação sobre as coisas; tudo é informação, mas o passo zero da pesquisa do museu, da pesquisa com objetos e artefatos, é a informação sobre ele. Então, não é tão simples assim você descrever esses objetos, você precisa aferir, e inferir informações, quando você não tem informações para dar uma biografia para aquele objeto. Então, eu aprendi como descrever esse objeto. Eu comecei no Museu Paulista, classificando, inventariando e tombando os objetos da coleção O Morar Paulistano. Enfim, isso tudo vai cair no fim da cadeia operatória, que vai dar no educador, no curador de exposição, outros processos desse emaranhado de ações.

Depois disso, tive experiências museológicas no Museu de Arqueologia e Etnologia, onde fui estagiário PAE [Programa de Aperfeiçoamento de Ensino], da pósgraduação, porque quando você é bolsista, você é convidado - obrigado - a fazer um estágio para aperfeiçoamento do ensino superior, então quem tem bolsa do governo federal é obrigado a se qualificar para ser professor do ensino superior, aí que entra o PAE. Eu fui fazer PAE, com uma professora de Arqueologia Mediterrânica, Maria Isabel D'Agostino Fleming, uma senhora espetacular, incrível, um poço de sabedoria arqueológica que estuda Itália; essa pessoa me ensinou um monte de coisa, aprendi mais ou menos como é desencadear uma disciplina no ensino superior, aprendi o que não fazer também, porque às vezes não concordei; e tive o contato com os alunos - e os alunos do ensino superior são muito difíceis [risos], às vezes eles querem as respostas das perguntas, não querem pensar sobre elas.

Hoje eu trabalho numa equipe sui generis. Eu não trabalho em um museu específico, mas eu trabalho com o grupo responsável por articular museus. Eu trabalho na Associação Cultural de Apoio ao Museu Casa de Portinari, mas eu estou lotado, nessa organização, na equipe de apoio ao Sistema Estadual de Museus de São Paulo, que é essa instância na Secretaria de Cultura e Economia Criativa que cuida 


\section{entrevista}

O museu como um prazer de vida

dos museus; ela qualifica e articula políticas públicas para o setor museal e, dentro desse processo, a gente tem uma atividade super importante que é o Cadastro Estadual de Museus, que é um mecanismo de certificação e apoio à organização de museus e eu trabalho nessa linha de frente. A minha equipe é volante, eu viajo o interior de São Paulo fazendo visitas técnicas, encontros com os profissionais de museus do estado nesse processo de ação. A minha organização tem sede na cidade de Brodowski - duvido que vocês já tenham ouvido falar; é uma micro cidade, entre Ribeirão Preto e Franca, onde nasceu o pintor Candido Portinari. Lá tem a casa dele, sui generis também; ele era de família humilde imigrante e a casa dele foi construída de puxadinhos, é um puxadinho histórico, que é o Museu Casa de Portinari. A minha Associação gere esse museu; o Museu Histórico e Pedagógico Índia Vanuíre, que lida com história e etnologia dos povos indígenas do oeste paulista, fica na cidade de Tupã; e o Museu Felícia Leirner, que é um museu de esculturas que fica na cidade de Campos do Jordão.

A gente tem um aspecto técnico, um aspecto teórico e um aspecto muito operacional também nessa equipe, então a gente vai desde escrever e produzir conteúdo, a pensar tecnicamente processos, a produzir eventos, então totalmente de acordo com a museologia e com a minha vontade de ser.

Revista Epígrafe: Puxando uma coisa que você falou, como que você vê essa interdisciplinaridade que é tão característica do campo da museologia?

Otávio Balaguer: É excepcional. Parece que eu tô repetindo muitas palavras elogiosas, parece que eu tô fazendo propaganda enganosa [risos], mas é verdade. Desde o começo da minha graduação eu abria várias portinhas, então pessoalmente eu tenho um perfil mais interdisciplinar e a história também não é uma coisa coesa, a gente 


\section{entrevista|}

Otávio Balaguer

tem vários campos. A museologia não é uma caixinha, mas uma cômoda inteira, o que você quiser colocar lá vai dar jogo, porque o museu é um fenômeno, uma tecnologia muito viva, é como cultura, se transforma o tempo inteiro, não tem começo, meio e fim, é processo. Museu é processo e isso cabe muito dentro da interdisciplinaridade e como eu sou uma pessoa interdisciplinar, eu adorei trabalhar em uma coisa que é processo. Os profissionais de museu falam que o [Fernand] Braudel era muito sábio, porque tem a longa duração, então os profissionais têm a consciência de que museu se faz na longa duração; se você não tiver paciência, você não dá conta, porque você não vê resultados hoje. Museu é isso, não dá para parar, se você para um processo dentro do museu, você faz um dominó cair todinho, então eu lido bem com isso.

Mas para você trabalhar com museu, você não precisa ser só apaixonado, porque não dá certo, enfim, eu acho que no mundo inteiro só a paixão não sustenta; você tem que ter paixão, amor, paciência e resiliência, porque tudo está junto, é um casamento. Você precisa ter vários elementos para continuar, porque às vezes você se frustra, porque uma coisa que a gente não pensa muito durante a graduação de história - porque é muito teórica - é sobre a profissionalização; agora esse debate tá em alta, porque o historiador vai ser profissionalizado, mas será que ele sabe o que significa ser profissionalizado? Será que ele entende quais são as consequências de você ser registrado? Enfim, eu acho que a gente tem que refletir sobre isso, porque a gente pode se frustrar no meio do caminho, e tudo bem também, mas eu tenho consciência. Eu acho que a gente precisa pensar mais sobre isso, sobre o que é ser um profissional da história, o que é ser um educador, porque a gente faz licenciatura também, mas aí a gente entra em outra questão: o historiador como educador tem que se qualificar no campo da educação, ele não está na natureza da formação dele aparentemente. Eu sinto que a gente faz muito isso na história, a gente pega e pula a 


\section{entrevista}

O museu como um prazer de vida

profissionalização. Talvez a gente precisasse discutir na graduação qual é o nosso diferencial, o que é ser profissionalmente historiador. Agora que a profissão foi regulamentada, qual é a atividade que o historiador executa? Qual é a qualificação própria dele? A gente tem que pensar essas coisas.

Revista Epígrafe: Nos tempos de pandemia, quais dificuldades você tem encontrado no trabalho com museus?

Otávio Balaguer: Então, pelo fato da minha equipe ser volante, por executar trabalhos em todo o Estado de São Paulo, nós viajamos muito, então a gente não tem uma base na cidade de São Paulo. Quando estamos em São Paulo, ou ficamos em reunião na Secretaria de Cultura com nossos colegas servidores, ou nós estamos em home office, então a gente já tem um mecanismo de home office muito bem estabelecido. Nós somos em cinco pessoas: tem a minha coordenadora e mais quatro; de nós, somos dois historiadores, duas artistas e uma musicista, mas todos com especialização em museologia - olha como a museologia é interdisciplinar -, e nós já trabalhamos nesse formato. Então para mim não foi um choque parar meu fluxo de trabalho e continuar aqui, porque temos plataformas virtuais, todas nossas planilhas, documentos; temos telefone do trabalho, internet, computador, nada disso é meu. E eu continuei nesse fluxo. Claro, não estamos fazendo uma série de coisas, porque eu ficava mais viajando que parado, então desregulou. Nesse sentido, eu senti muita falta do meu deslocamento, porque eu gosto de estar em contato com os museus de todo estado.

Os museus estão fechados nesse momento, isso é muito complicado para mim, eu entendo completamente a necessidade, óbvio, não sou um negacionista, só que vejo que as pessoas estão demorando muito para discutir o espaço do museu como um espaço importante nesse contexto. Agora que as atividades já estão sendo 


\section{entrevista|}

Otávio Balaguer

retomadas, eu não acho que é óbvio e lógico que um shopping deva abrir e um museu deve ficar fechado. Há pessoas que acham que todos devem ficar fechados, tudo bem, mas se com os níveis de infecção diminuindo, eu acho que psiquicamente e socialmente, você poder voltar a visitar um espaço museal é excepcional, eu acho que faz parte do processo de cura. Veja, eu não estou falando que tem que acabar o isolamento e abrir tudo, não me interpretem mal, eu também acho que as equipes têm que se proteger, mas eu acredito que pode existir a possibilidade de você fazer uma visita a um museu proximamente, a Prefeitura de São Paulo está negociando a abertura para os próximos tempos; eu acho possível, importante e necessário, porque a gente tem um espaço social que pode ser apagado nesse processo. As pessoas não podem deixar de olhar para as nossas atividades cotidianas, como o museu, que é um espaço de convivência, não uma vitrine - eu não vou ao museu numa perspectiva de consumo, eu não gero renda quando vou ao museu, mas os museus geram rendas também; é um espaço essencial para a vida em sociedade, um espaço de fortalecimento. Em muitas comunidades, o museu foi o elo para segurar eles em pé, o centro de referência, ele pode funcionar como um espaço de acolhida para serviços públicos, em caso de necessidade, tomando o cuidado com a coleção e tudo mais; o museu pode ser em último caso, até um hospital de campanha.

O museu tem essa função de responder a pandemia de maneira virtual, ele esteve muito presente nas redes, eu acho isso super importante, estamos fazendo ações o tempo todo para produzir espaços na rede, mas o museu também deveria estar começando a pensar em reabrir. Aqui não falo em nome de nenhum museu, cada um tem a sua gestão, as suas ações para fazer essa abertura, mas eu, pessoalmente, acho que é um espaço que está fazendo muita falta para minha saúde mental, eu digo que eu conseguiria fazer uma visita com muita tranquilidade, segurança, e isso traria um momento de bem estar muito maior para mim do que eu 


\section{entrevista}

O museu como um prazer de vida

fazer uma compra no shopping, ou no centro comercial, etc.

Revista Epígrafe: Pensando no historiador no espaço do museu, quais seriam as habilidades exigidas desse profissional nesse espaço?

Otávio Balaguer: Eu acho que a metodologia do trabalho em história. O historiador tem método de pesquisa; o olhar; o arcabouço, isso é excepcional. O historiador que se graduou de uma maneira empenhada, que estava ali no processo todo, ele tem um arcabouço que vai trazer muita perspectiva para o trabalho profissional dele, ele vai conseguir ter uma boa leitura dos problemas. O historiador tem uma capacidade de resolução de problemas muito grande e às vezes a gente não pensa sobre isso, mas quando você se dá conta que durante todo o processo da graduação a gente está recebendo questões e resolvendo questões, isso é excepcional; você tem uma capacidade de resolução de problemas que é super importante para o trabalho, e isso vem com a pesquisa também. De certo modo o central que um historiador tem a oferecer em um museu é a pesquisa, a capacidade de localizar as coisas e de promover novas leituras e eu acho que isso é muito importante.

Revista Epígrafe: Para finalizar, quais dicas você daria para um estudante interessado em trabalhar nessa área, os museus?

Otávio Balaguer: O que eu acho importante para o historiador que quer trabalhar em museus é iniciar uma trajetória de estudos museológicos, de estudar museus, os processos e isso depende da abordagem que ele quer dar, porque existem várias perspectivas dentro dos museus. Sem dúvidas, tem que inserir no processo formativo a gavetinha do museu, dentro das áreas que já existem; e se você curte educação, 


\section{entrevista|}

Otávio Balaguer

precisa estudar educação museal; se você gosta de administrar coisas, organizar coisas, você pode estudar gestão; se você gosta de história dos museus, não tem nem o que falar, tem muita coisa; e teoria museológica mais ainda! Não é difícil achar isso e esse com certeza vai ser o diferencial do historiador que pleiteia colaborar com o mundo dos museus e ele já vai chegar no mundo museológico com recursos para entender, para operar dentro dele, porque o museu tem essa dimensão teórica e essa dimensão técnica muito grande eu acho que andar essas casinhas da qualificação no campo da museologia é o segredo para o historiador. E viver o museu, porque museu é processo; é experiência; museu é vida! Então, assim, se os museus não estiverem nos seus planos, em qualquer atividade que você for fazer perto de um museu, alguma coisa está errada [risos]. 